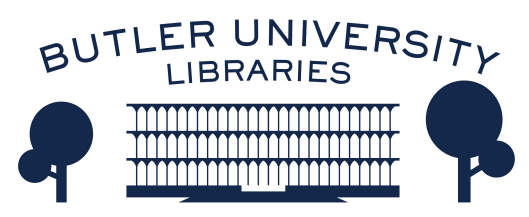

Journal of Hindu-Christian Studies

\title{
Book Review: "The Truth, the Way, the Life: Christian Commentary on the Three Holy Mantras of the Srivaisnava Hindus"
}

Tracy Sayuki Tiemeier

Follow this and additional works at: https://digitalcommons.butler.edu/jhcs

Part of the Religion Commons

\section{Recommended Citation}

Tiemeier, Tracy Sayuki (2009) "Book Review: "The Truth, the Way, the Life: Christian Commentary on the Three Holy Mantras of the Srivaisnava Hindus"," Journal of Hindu-Christian Studies: Vol. 22, Article 15. Available at: https://doi.org/10.7825/2164-6279.1442

The Journal of Hindu-Christian Studies is a publication of the Society for Hindu-Christian Studies. The digital version is made available by Digital Commons @ Butler University. For questions about the Journal or the Society, please contact cbauman@butler.edu. For more information about Digital Commons @ Butler University, please contact digitalscholarship@butler.edu. 
bhajans. Norman concludes the study by posing a pertinent question in chapter eight, "Sing to the Lord a New Song", which remains true for all diaspora communities: what native elements are perpetuated and altered as they are transmitted to the next generation. She infers, in England, secular music has influenced the British Indian Christian worship music and, in Trinidad and Tobago, Afro-Caribbean community music has affected Asian Christian worship. In both instances, they represent a fusion of the Indian and the Western styles.

Clearly, then, the Indian Christian worship in its native context affirms Indian Christianity, which is heterogeneous -- as an amalgam of native Hindu traditions and Western Christian traditions; and in its transplanted context acculturates to the current context, adding to its existing complexity and diversity representing a blending of the East and the West. In this regard, Indian Christian diaspora forges a new wave of Christian worship singing with a purpose to perpetuate and navigate religious and cultural identities. Here, they construct a new Indian Christianity, which is neither totally Indian nor Western--ritualizing on the boundaries--as Indian Hindu diaspora. This study may be beneficial in discussing issues of acculturation and Hindu-Christian encounters within Chrïstian worship in its native and diaspora contexts as it corroborates existing scholarship on medieval Hindu bhakti traditions and Western influences, highlighting the nuances of Indian diaspora Christian worship.

George Pati

Valparaiso University

\section{The Truth, the Way, the Life: Christian Commentary on the Three Holy Mantras of the Srivaisnava Hindus. Francis X. Clooney, S.J. Leuven and Grand Rapids: Peeters Publishers and Wm. B. Eerdmans Publishing Company, 2008, 202 pp.}

THIS book is a delightful and thought provoking Christian commentary on the three holy Mantras of the Srivaisnava Hindu tradition. These Mantras express the core truths of Srivaisnava belief and practice. Francis X. Clooney, S.J., carefully exegetes the Mantras in their Srivaisnava context and reflects on the implications of the Mantras for Christian thought and practice. Clooney's perspective and primary audience is Christian; but his commentary is more broadly of interest to those in Srivaisnava studies, Hindu-Christian dialogue, and interreligious/comparative theology.

Clooney begins with a helpful methodological reflection on (interreligious) commentary. Commentary is both academic discipline and spiritual practice. As such, it requires more than hermeneutical skills; it requires submission to the truths of the text. The reader must enter the world of the text as much as possible and read in openness to the meanings and values disclosed by the text. To specify a Christian commentary is therefore somewhat problematic, as it foregrounds the reader, rather than the text. And yet, being aware of the attitudes of the interreligious reader highlights that one can learn from the sacred texts of another tradition.

Clooney depends heavily on Vedanta Desika's (1268-1369) commentary on the Mantras, and organizes the Mantras according to three primary themes in Desika's commentary: the Truth, the Way, and the Life. This grounds the reader in Srivaisnava thought on the Mantras, but also points the Christian reader toward an interreligious bridge; for the Christian reader cannot help but think of the Gospel of John: "I am the way, and the truth, and the life. No one comes to the Father except through me (John 14.6, NRSV)."

Chapter One focuses on the Truth, revealed in the Tiru Mantra: "Aum, obeisance to Narayana." According to Desika, fundamental 
truths on the nature of Narayana and the utter dependence of humanity on Narayana are communicated by the Mantra. From a Christian perspective, one does not need to accept the identity of Narayana in order to rethink Christian truths of God and human dependence on God. The Tiru Mantra also enriches Christian prayer. Clooney juxtaposes the Mantra with Henri Le Saux's (Abhishiktananda, 1910-1973) use of "Abba, Father" as a Christian Mantra. Although Christians may not unequivocally pray with the Tiru Mantra, they can pray with the universal truths communicated by it.

Chapters Two and Three focus on the Way. Chapter Two examines the first line of the Carama Sloka (Bhagavad Gita 18.66a): "Having completely given up all dharmas, to Me alone come for refuge." For Desika, the Mantra does not dictate complete renunciation; rather one should follow dharmic duties realizing Krsna's initiative as truly essential. Clooney points to Bede Griffiths (1906-1993), who correlates giving up dharma and Christian freedom from the law. The priority is on a God who speaks to us and initiates transformation. Clooney also reflects on the Gospel of Matthew: "If you would be perfect, go, sell your possessions and give the proceeds to the poor...(19.21a)" While Krsna's call to "Me alone" may be problematic for Christians, Christians are still called to listen and surrender to the divine word.

Chapter Three looks at the Way, expressed in the Dvaya Mantra: "I approach for refuge the feet of Narayana with Sri; obeisance to Narayana with Sri." Here, Narayana with Sri is the Way, but also the Goal. The Mantra also reveals divine qualities, human surrender, and religious practice. Although Narayana with Sri may compare with the Christian Trinity, the specificity of persons (and gender) may be problematic for Christians. Nevertheless, Clooney pairs the Mantra with the Gospel of Luke, where Jesus on the cross declares, "Father, into your hands I commit my spirit (23.46)." Christians praying with the Mantra learn a deeper sense of surrender.

Chapter Four focuses on Life, shown in the second line of the Carama Sloka (Bhagavad Gita 18.66b): "From all sins I will make you free. Do not grieve." This line reveals the divine response to human surrender: the Life free from sins and grief. For Desika, liberation is not an immediate absence of sin; rather, it is an unfolding process of human cooperation and response to divine initiative. Because of this promise for liberation, the human is given no reason for grief. Clooney places this line in conversation with the Gospel of Matthew, "...You will have treasure in heaven; and come, follow $\mathrm{Me}$ (19.21b)." Christian prayer entails surrendering to change that comes in a life lived according to divine invitation.

Chapter Five offers further reflection after the commentary. Clooney looks at what openings have now been created in Christian theology, theology of religions, ethics, scripture, and prayer. Although Clooney recognizes that there are obstacles preventing Christians from praying the Mantras as a Srivaisnava would, he argues that the Mantras nevertheless offer Christians deep theological and spiritual insight.

As Clooney presumes a Christian audience, much of the Christian theology and references to Christian scripture will be understood. Nevertheless, there is a certain imbalance with how Christian references are treated. Readers would benefit from greater grounding of the Christian sources in Christian theological and biblical commentary.

This minor point aside, the book is an outstanding piece of interreligious commentary that brings together detailed exegesis and constructive theological reflection. Clooney shows how beneficial interreligious reading can be, and leads the reader to a greater understanding of other and self.

The commentary is quite dense. However, Clooney provides numerous charts and wider theological reflections that make the book more accessible for those not expert in Srivaisnava theology. Most appropriate for advanced students and specialists, this commentary will be deeply rewarding for anyone willing to read carefully and take up Clooney's challenge to become an interreligious reader, intellectually and spiritually.

Tracy Sayuki Tiemeier

Loyola Marymount University 